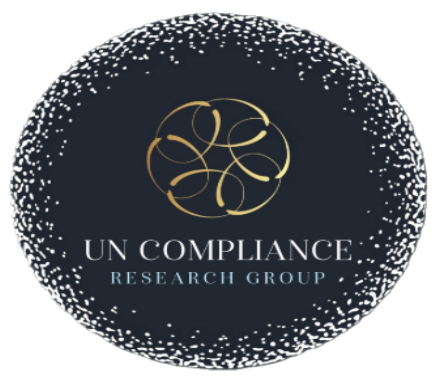

The UN Compliance Research Group

Presents the

\title{
2019: ICJ Judgments Jadhav (India V. Pakistan) Final Compliance Report
}

17 July 2019 - 11 July 2020
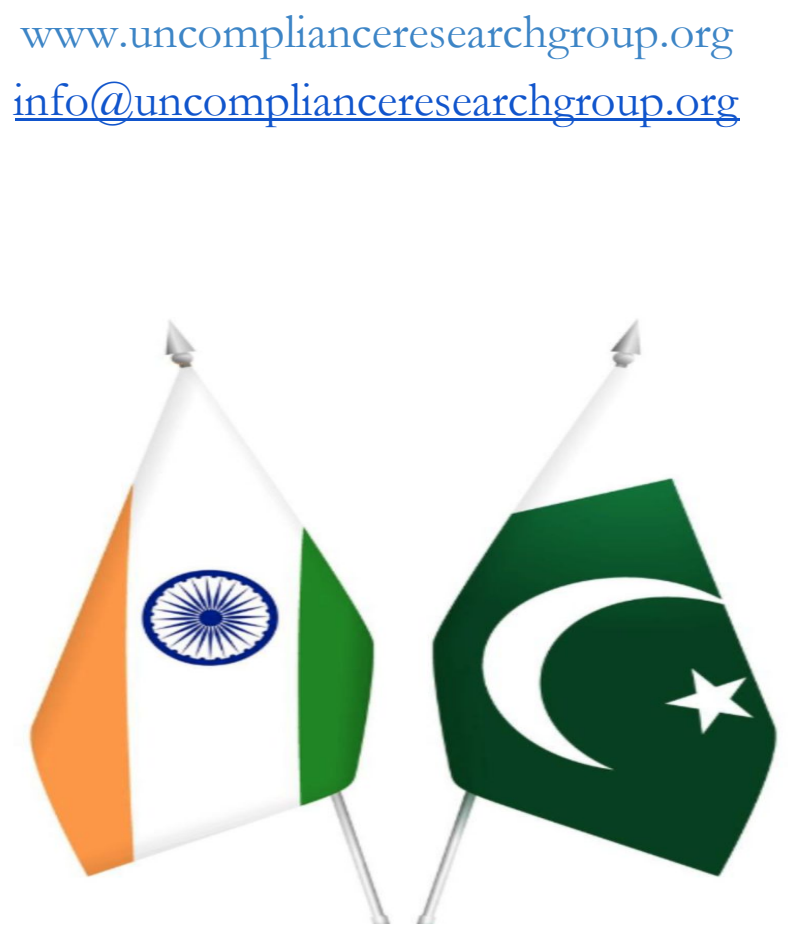

Authorship: Omar S. Abdellatif, Ali Behbehani and Stevan Lepank 


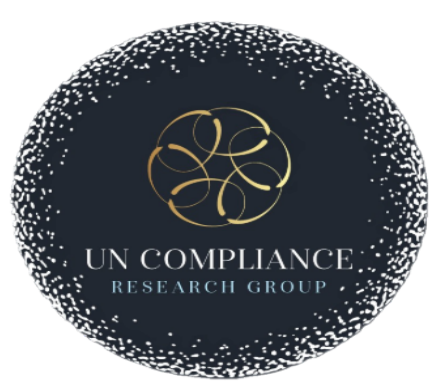

\section{Perface}

Since its establishment the UN Compliance Research Group has produced reports on states compliance with UN resolutions,verdicts made by the ICJ and WHO guidelines. These reports monitor each state's efforts to implement a carefully chosen selection of the many commitments produced at UN summits, ICJ cases and WHO. The reports are offered to the general public and to policy makers, academics, civil society, the media and interested citizens around the world in an effort to make the work of the UN, ICJ and WHO more transparent, accessible and effective, and to provide scientific data to enable the meaningful analysis of the causes of compliance and the impact of those important informal international institutions. To make its assessments, the UN Compliance Research Group relies on publicly available information, documentation and media reports. To ensure accuracy, comprehensiveness and integrity, we encourage comments from stakeholders. Indeed, scores can be recalibrated if new material becomes available. All feedback remains anonymous. Responsibility for the contents of this report lies exclusively with the authors and analysts of the UN Compliance Research Group.

\section{Introduction and Summary}

The 2019: ICJ Judgments Jadhav (India V. Pakistan) Final Compliance Report is prepared by the UN Compliance Research Group. The report analyzes compliance by the Islamic Republic of Pakistan and the Republic of India with the ICJ verdicts on the Jadhav case issued on 17 July 2019. The report covers relevant actions taken by the two states between 17 July 2019 to 10 July 2020.

\section{Methodology and Scoring System}

This report draws on the methodology developed by the G8 Research Group, which has been monitoring G7/8 compliance since 1996 (the International Organisations Research Institute at the Higher School of Economics (IORI HSE) joined this multiyear project in 2005, and Bond University participated in 2014). The use of this methodology builds cross-institutional and cross-member consistency and also allows compatibility with compliance assessments of other institutions. The methodology uses a scale from -1 to +1 , where +1 indicates full compliance 


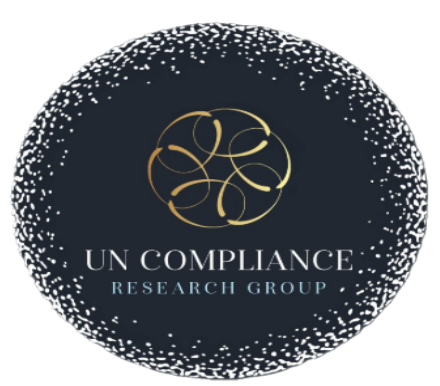

with the stated commitment, -1 indicates a failure to comply or action taken that is directly opposite to the stated instruments or goal of the commitment, and 0 indicates partial compliance or work in progress, such as initiatives that have been launched but are not yet near completion and whose full results can therefore not be assessed. Each member assessed receives a score of $-1,0$ or +1 for each commitment. For convenience, the scores in the tables have been converted to percentages, where -1 equals 0 per cent and +1 equals 100 per cent.

\section{Commitment Breakdown}

The ICJ made a total of seven main obligations at the Jadhav Case final judgement. These commitments, as identified by the UN Compliance Research Group, are drawn from the official 2019 ICJ Summary of Judgment on the Jadhav Case.

\section{Selection of Commitments}

For each ICJ case, the research team selects commitments that reflect the breadth of the ICJ verdicts and also reflect the priorities of the Court's judgement, while balancing the selection to allow for comparison with past and future judgments. The selection also replicates the breakdown of issue areas and the proportion of commitments in each one. Primary criteria for priority commitment selection are the comprehensiveness and relevance to the case, the ICJ and the world, as well as individual and collective pledges. Selected obligations must also meet secondary criteria of performance measurability and ability to comply to some degree within a year, as well as tertiary criteria of significance as identified by scientific teams and relevant stakeholders in the countries involved.

\section{Jadhav Case}

Background:

Mr. Kulbhushan Jadhav is an Indian national and was arrested on March 3rd, 2016, in the Pakistani province of Balochistan on charges of spying for India's intelligence agency and and terrorism. On the 23rd of January 2017, India stated that Pakistan has requested assistance in the investigation of Mr.Jadhav's alleged "involvement in espionage and terrorist activities." On the 21st of March 2017, Pakistan requested India to grant consular access to Mr.Jadhav to assist 


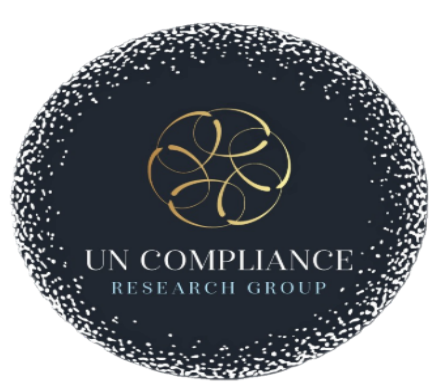

in the investigation. India claimed that this act of "assistance in the investigation process to the grant of consular access" was a serious violation of the Vienna Convention.

On the 8th of May 2017, The Islamic Republic of Pakistan was accused "for egregious violations of the Vienna Convention on Consular Relations” by the Republic of India, in the trial of Mr. Kulbhushan Sudhir Jadhav, who was sentenced to death by a military court in Pakistan. The Court's jurisdiction notes that the Applicant invoked Article 36, paragraph 1, of the Statute of the Court. Also, on the 8th of May, India filed a request noting that the alleged violation of the Vienna Convention by Pakistan has prevented India from exercising their rights and deprived the Indian national from the protection accorded under the Convention. Mr.Jadhav "will be subjected to execution unless the Court indicates provisional measures directing the Government of Pakistan to take all measures necessary to ensure that he is not executed until the Court's decision on the merits" of the case, as claimed by the Applicant. India claimed the execution would cause "irreparable prejudice to the rights claimed by India." The President of the Court was also said to exercise his power under Article 74, paragraph 4, regarding the Rules of the Court. The President of the Court also called upon Pakistan on the request for the indication of Provisional measures on a letter dated on the 9th of May 2017.

On the 15th of May 2017, following the public hearing, the provisional measures presented by India were delivered and the Court delivered its order on the 18th of May 2017. The order indicated that Pakistan should take all measures to not execute Mr.Jadhav and that Pakistan should inform the Court of all measures taken in the process of implementing the order.

By the ICJ Court Order on the 13th of June 2017, The President of the Court, President Abdulqaqi Yusuf, fixed the 13th of September 2017 and the 13 of December 2017 as the representative time-limits for the filing of a memorial by India and a counter-memorial by Pakistan.

The Court, having heard the reached agreement between both parties, later authorized the submission of a Reply by India and a Rejoinder by Pakistan. Held on the 17th of April 2018 and the 17 th of July 2018 respectively. 


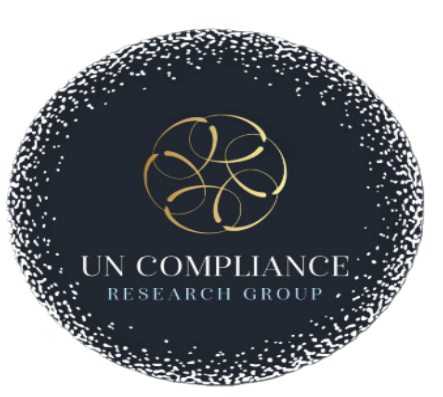

On the 17th of July 2019, The ICJ finds the Islamic Republic of Pakistan has acted in breach of the obligations with regards to Article 36 of the Vienna convention on Consular Relations, in the matter of an Indian national, Mr. Jadhav.

\section{Assessment}

\begin{tabular}{|l|c|c|c|}
\hline \multicolumn{1}{|c|}{ Country } & No Compliance & Partial Compliance & Full Compliance \\
\hline India & & $\mathbf{0}$ & \\
\hline Pakistan & & $\mathbf{0}$ & \\
\hline
\end{tabular}

\section{Countries Obligations ${ }^{1}$}

1. Pakistan is required to arrange for Mr. Jadhav's legal representation.

2. Pakistan is under obligation to inform Mr. Jadhav of his rights and grant access to the consular offices of India to visit Mr. Jadhav.

3. Pakistan is required to fully comply with its obligations under Article 36 of the Vienna Convention.

4. Pakistan, has the obligation to provide effective review and reconsideration of the conviction of Mr. Jadhav. However, Pakistan can choose its own means for complying with this obligation.

5. A continued stay of execution constitutes an indispensable condition for the effective review and reconsideration of the conviction of Mr. Jadhav.

6. The ICJ denies India's claim that declares the sentence handed down by Pakistan's military court is violative of international law and is not part of the Covenant but a part of the Vienna Convention.

7. The ICJ finds the submissions mentioned below made by India cannot be upheld. The first one being entitling India to restitutio in integrum and its request to annul the decision of the military court and to restrain Pakistan from giving effect to the sentence or conviction. To direct Pakistan to take steps to annul the decision of the military court. To release Mr. Jadhav and to facilitate his safe passage to India.

\section{Scoring Guidelines (Pakistan)}

\begin{tabular}{|c|l|}
\hline-1 & $\begin{array}{l}\text { State does not comply with Article } 36 \text { of the Vienna Convention, nor does it provide } \\
\text { Jadhav with legal representation, consular access, information on rights and it does not take } \\
\text { measures to effectively review the conviction of Jadhav. }\end{array}$ \\
\hline 0 & $\begin{array}{l}\text { State partially complies with Article } 36 \text { of the Vienna Convention through implementing at } \\
\text { least } 3 \text { of the ICJ assigned obligations either by providing Jadhav with legal representation, }\end{array}$ \\
\hline
\end{tabular}

\footnotetext{
1 Jadhav case (India v. Pakistan), International Court of Justice, (Hague), 17 July 2019. Access Date: 08 July 2020. https://www.icj-cij.org/files/case-related/168/168-20190717-SUM-01-00-EN.pdf
} 


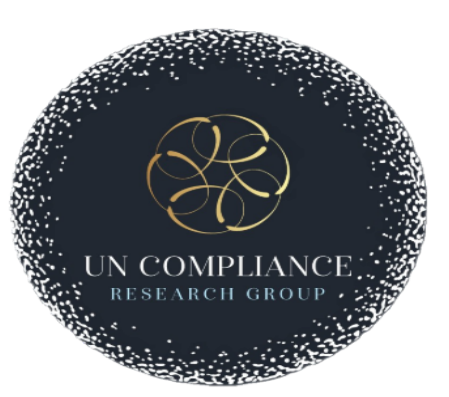

\begin{tabular}{|c|l|}
\hline & $\begin{array}{l}\text { consular access, information on rights or implementing measures to effectively review the } \\
\text { conviction of Jadhav. }\end{array}$ \\
\hline+1 & $\begin{array}{l}\text { State fully complies with Article } 36 \text { of the Vienna Convention through implementing all ICJ } \\
\text { assigned obligations by providing Jadhav with legal representation, consular access, } \\
\text { information on rights and implementing measures to effectively review the conviction of } \\
\text { Jadhav }\end{array}$ \\
\hline
\end{tabular}

\section{Islamic Republic of Pakistan: 0}

Pakistan has partially complied with the ICJ verdicts on the Jadhav case through binding with Article 36 of the Vienna Convention and providing Jadhav with consular access, legal representation and informing him of his legal rights. Yet Pakistan did not set a plan of action or taken practical measures to review Jadhav's conviction.

On 2 September 2019, Pakistan granted consular access to India for the Indian national Kulbhushan Jadhav. ${ }^{2}$ A statement issued by Pakistan's Foreign Office stated, “As a responsible member of the international community and in line with our international commitments, Pakistan has provided unimpeded, uninterrupted consular access to India to Commander Jadhav". "The consular access was provided for a two hours duration to the Indian High Commission in Islamabad, with no restrictions placed by Pakistani authorities on the language of communication. ${ }^{4}$

On 13 November 2019, the Spokesman of the Pakistan's Armed Forces Major General Asif Ghafoor, announced that Pakistan considers Various legal options for review and reconsideration of Jadhav's case. ${ }^{5}$ Ghafoor denied reports that the Pakistani government was preparing to amend the Army Act to implement the ICJ's verdict. ${ }^{6}$

\footnotetext{
2 Indian Diplomat meets spy Jadhav for two hours, Dawn Newspaper, (Islamabad) 03 September 2019. Access Date: 19 May 2020. https://www.dawn.com/news/1503185 ${ }^{3}$ Indian Diplomat meets spy Jadhav for two hours, Dawn Newspaper, (Islamabad) 03 September 2019. Access Date: 19 May 2020. https://www.dawn.com/news/1503185 ${ }^{4}$ Indian Diplomat meets spy Jadhav for two hours, Dawn Newspaper, (Islamabad) 03 September 2019. Access Date: 19 May 2020. https://www.dawn.com/news/1503185 ${ }^{5}$ Pakistan considering various legal options for review of Kulbhushan Jadhav's case: Army, The Economic Times, (Islamabad) 13 November 2019. Access Date: 03 June 2020. https://economictimes.indiatimes.com/news/defence/pakistan-considering-various-legal-options-for-re view-of-kulbhushan-jadhavs-case-army/articleshow/72042747.cms

${ }^{6}$ Pakistan considering various legal options for review of Kulbhushan Jadhav's case: Army, The Economic Times, (Islamabad) 13 November 2019. Access Date: 03 June 2020. https://economictimes.indiatimes.com/news/defence/pakistan-considering-various-legal-options-for-re view-of-kulbhushan-jadhavs-case-army/articleshow/72042747.cms
} 


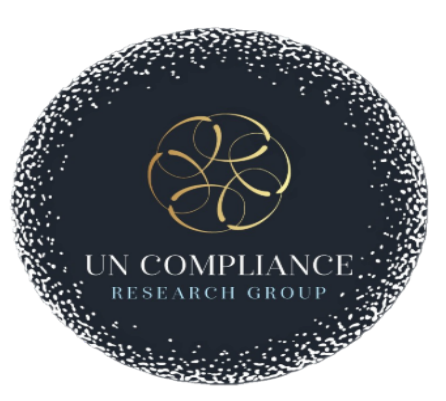

On 14 May 2020, the Foreign Office spokesperson Aisha Farooqui announced that Pakistan is implementing measures to ensure the review of the Kulbhushan Jadhav case in accordance with the ICJ's verdict. ${ }^{7}$ Farooqui stated, "Being a responsible state, Pakistan abides by all its international obligations and will continue doing so". ${ }^{8}$

On 08 July 2020, Pakistan's Attorney General Ahmed Irfan and Director General Zahid Hafeez Chaudhry announced that Kulbhushan Jadhav refused to file a review petition to the Islamabad High Court, against his conviction and death penalty assigned by a military court. ${ }^{9}$ The Pakistani officials announced that Jadhav has decided to alternatively apply for a mercy petition. ${ }^{10}$ Pakistan's Foreign Office spokesperson Aisha Farooqi stated that Pakistan has invited India to file the "review and reconsideration petition" on the behalf of Jadhav after his refusal to do so. ${ }^{11}$

On 08 July 2020, Pakistan's Director General Zahid Hafeez Chaudhry announced that Pakistan has offered Kulbhushan Jadhav consular access for a second time. ${ }^{12}$ In addition to offering Jadhav a meeting with his wife and father. ${ }^{13}$

Pakistan has partially complied with the ICJ verdicts on the Jadhav case through providing Jadhav with consular access, legal representation and informing him of his legal rights but not implementing practical measures to review the conviction. Thus, it receives a score of 0 .

\section{Scoring Guidelines (India)}

\footnotetext{
${ }^{7}$ Pakistan processing steps to ensure review of Kulbhushan Jadhav case: FO, Deccan Herald, (Islamabad) 14 May 2020. Access Date: 03 June 2020.

https://www.deccanherald.com/international/pakistan-processing-steps-to-ensure-review-of-kulbhusha n-jadhav-case-fo-837643.html

${ }^{8}$ Pakistan processing steps to ensure review of Kulbhushan Jadhav case: FO, Deccan Herald, (Islamabad) 14 May 2020. Access Date: 03 June 2020.

https://www.deccanherald.com/international/pakistan-processing-steps-to-ensure-review-of-kulbhusha n-jadhav-case-fo-837643.html

${ }^{9}$ Indian spy Jadhav refused to file review petition in IHC despite Pakistan's offer, officials say, Dawn Newspaper, (Islamabad) 08 July 2020. Access Date: 08 July 2020.

https://www.dawn.com/news/1567762/indian-spy-jadhav-refused-to-file-review-petition-in-ihc-despitepakistans-offer-officials-say

${ }^{10}$ Indian spy Jadhav refused to file review petition in IHC despite Pakistan's offer, officials say, Dawn Newspaper, (Islamabad) 08 July 2020. Access Date: 08 July 2020.

https://www.dawn.com/news/1567762/indian-spy-jadhav-refused-to-file-review-petition-in-ihc-despitepakistans-offer-officials-say

${ }^{11}$ Indian spy Jadhav refused to file review petition in IHC despite Pakistan's offer, officials say, Dawn Newspaper, (Islamabad) 08 July 2020. Access Date: 08 July 2020.

https://www.dawn.com/news/1567762/indian-spy-jadhav-refused-to-file-review-petition-in-ihc-despitepakistans-offer-officials-say

${ }^{12}$ Indian sentenced to death in Pakistan for spying 'refused to file review', Arab News, (Islamabad) 08 July 2020. Access Date: 08 July 2020. https://www.arabnews.com/node/1701901/world

${ }^{13}$ Indian sentenced to death in Pakistan for spying 'refused to file review', Arab News, (Islamabad) 08 July 2020. Access Date: 08 July 2020. https://www.arabnews.com/node/1701901/world
} 


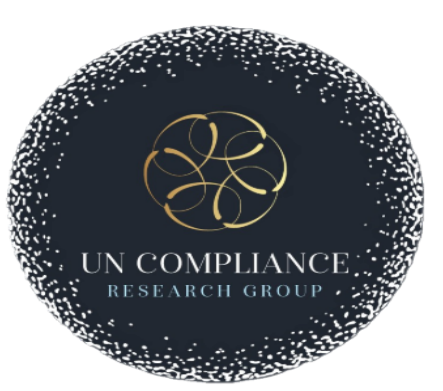

\begin{tabular}{|c|l|}
\hline-1 & $\begin{array}{l}\text { State does not comply with statements made by the ICJ regarding the release and freedom } \\
\text { of Mr. Jadhav. In addition, the State fails to accept the remedies of the ICJ regarding the } \\
\text { judgment of the Pakistani military court on Mr. Jadhav. Also, the ICJ's statement in regard } \\
\text { to entitling India to restitutio in integrum and its request to annul the decision of the } \\
\text { military court and to restrain Pakistan from giving effect to the sentence or conviction. } \\
\text { Finally, the ICJ's statement regarding the sentence given by the Pakistani government that } \\
\text { violates international law. }\end{array}$ \\
\hline 0 & $\begin{array}{l}\text { State partially complies with statements made by the ICJ regarding the release and freedom } \\
\text { of Mr. Jadhav. In addition, the State fails to accept the remedies of the ICJ regarding the } \\
\text { judgment of the Pakistani military court on Mr. Jadhav. Also, the ICJ's statement in regard } \\
\text { to entitling India to restitutio in integrum and its request to annul the decision of the } \\
\text { military court and to restrain Pakistan from giving effect to the sentence or conviction. } \\
\text { Finally, the ICJ's statement regarding the sentence given by the Pakistani government that } \\
\text { violates international law. }\end{array}$ \\
\hline+1 & $\begin{array}{l}\text { State fully complies with statements made by the ICJ regarding the release and freedom of } \\
\text { Mr. Jadhav. In addition, the State fails to accept the remedies of the ICJ regarding the } \\
\text { judgment of the Pakistani military court on Mr. Jadhav. Also, the ICJ's statement in regard } \\
\text { to entitling India to restitutio in integrum and its request to annul the decision of the } \\
\text { military court and to restrain Pakistan from giving effect to the sentence or conviction. } \\
\text { Finally, the ICJ's statement regarding the sentence given by the Pakistani government that } \\
\text { violates international law. }\end{array}$ \\
\hline
\end{tabular}

\section{The Republic of India: 0}

India has partially complied with the obligations set out by the ICJ by not requesting to entitle a restitutio in integrum. Yet, India pursued to fight for the release of Mr. Jadhav strongly opposed the legitimacy of Jadhav's trial by a Pakistani military court, despite the ICJ overruling India's claim in this regard.

On 19 July 2019, India's Minister of External Affair S.Jaishankar urged Pakistan to "release and repatriate" Mr. Jadhav. Furthermore, he mentioned that the Indian government will "vigorously continue its efforts to ensure Jadhav's safety and well-being as well as his early return to India." ${ }^{14}$

On 08 July 2020, India's External Affairs Ministry stated that "Pakistan has obviously coerced Shri Jadhav to forego his rights to seek an implementation of the judgment of the ICJ." India also claims that Pakistan

\footnotetext{
${ }^{14}$ Jaishankar urges Pak to Free Jadhav immediately, The Asian Age, (New Delhi) 19 July 2019. Access Date: 08 July 2020.https://www.asianage.com/india/all-india/190719/jaishankar-urges-pak-to-free-jadhav-immediate ly.html
} 


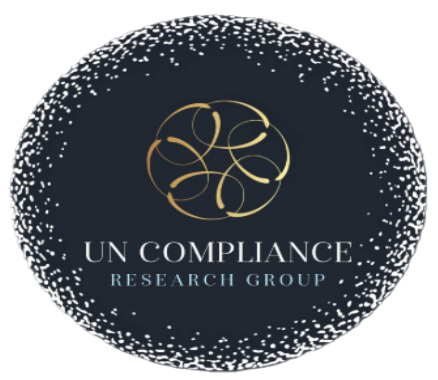

"had all along maintained their laws for review and reconsideration. Now after almost a year, they have made a U-turn.” India expresses that this violates the ICJ judgment made regarding the case. ${ }^{15}$

India has partially compiled with the obligations set out by the ICJ when it comes to requesting to entitle a restitutio in integrum but, still fought for the release of Mr. Jadhav and opposed the final judgment the Pakistani court made regarding the case. Thus, it receives a score of 0 .

\section{Conclusion}

The Islamic Republic of Pakistan and the Republic of India both partially complied with the ICJ verdicts on the Jadhav Case, issued on the 17 th of July 2019. The report covered compliance actions taken by Pakistan and India between July 2019 - July 2020. Pakistan has partially complied with the ICJ verdicts on the Jadhav case through binding with Article 36 of the Vienna Convention and providing Jadhav with consular access, legal representation and informing him of his legal rights. However, Pakistan did not set a plan of action or taken practical measures to review Jadhav's conviction. India has partially complied with the obligations set out by the ICJ by not requesting to entitle a restitutio in integrum. Yet, India pursued to fight for the release of Mr. Jadhav strongly opposed the legitimacy of Jadhav's trial by a Pakistani military court, despite the ICJ overruling India's claim in this regard. Pakistan and India may resort again to the ICJ if full compliance to Jadhav Case 2019 verdicts is not achieved by both states.

${ }^{15}$ Kulbhushan Jadhav coerced into refusing appeal, says India, Special Correspondent, (New Delhi) 08 July 2020. Access Date: 08 July 2020. https://www.thehindu.com/news/international/jadhav-refused-to-file-review-petition-against-his-death-s entence-claims-pakistan/article32020510.ece 